\title{
Problematika Teater Pakeliran sebagai Konsep Garap dalam Seni Pewayangan
}

\author{
I Gusti Made Darma Putra \\ Program Studi Seni, Program Doktor, Program Pascasarjana, \\ Institut Seni Indonesia Denpasar \\ Jalan Nusa Indah Denpasar Bali \\ 081246488312/dalangcilik@gmail.com
}

\begin{abstract}
The usage of Balinese screen puppetry concept have been increasing around ISI Denpasar students. Despite its popularity, the practice tense to put aside the process of concept arrangement which is the foundation of a creation to be approved. This qualitative research with analytic descriptive method of analysing use the theory of art form, art commentary, and art value to analyze main discussion such as: 1) Screen puppetry concept in puppet performance, 2) Problems of screen puppetry theatre concept 3) The potency of screen puppetry theatre concept as a value. Authors analysis discover: 1) As a form which is the combination of 'theatre' and 'screen puppetry' each represent branch of knowledge which is 'Drama' that is identical with theatrical elements, and 'puppetry' which is popular as a flat puppet performance behind the screen. 2) The needs of mapping and formulation of screen puppetry theatre concept to answer the problem existing. 3) Formulated screen puppetry theatre as a thinking concept and teaching method with a theoretical and practice application for an aesthetic valuation, institutional and social purpose
\end{abstract}

Keywords: screen puppetry theatre, problems, puppetry

\begin{abstract}
ABSTRAK
Konsep teater pakeliran dalam penciptaan karya seni eksperimental oleh mahasiswa pedalangan ISI Denpasar semakin populer dan sering digunakan. Di balik popularitasnya, budaya praktek dalam aplikasinya sering mengesampingkan proses berkonsep sebagai pondasi awal garap karya seni yang dapat dipertanggung jawabkan. Model penelitan kualitatif dengan analisis deskriptif analitik ini, menggunakan teori bentuk seni, kritik seni, dan teori nilai guna menganalisis pokok bahasan: 1) Konsep teater pakeliran dalam pertunjukan wayang, 2) Problematika konsep teater pakeliran, 3) Potensi konsep teater pakeliran sebagai nilai. Penulis mengemukakan bahwa: 1) Sebagai sebuah bentuk bermakna 'teater' dan 'pakeliran' masing-masing mewakili cabang ilmu yaitu 'drama' yang identik dengan unsur teatrikal, serta 'pewayangan' dikenal dengan pementasan boneka pipih dibalik kelir. 2) Perlunya pemetaan dan formulasi dalam konsep teater pakeliran yang mampu menjadi solusi problematika yang kerap terjadi. 3) Formulasi teater pakeliran sebagai sebuah konsep berfikir dan metode mengajar dengan aplikasi teoritis dan praktis demi penilaian estetik kelembagaan dan sosial.
\end{abstract}

Kata kunci: teater pakeliran, problematika, pewayangan

\section{PENDAHULUAN}

Seni pewayangan bisa hidup hingga kini karena berbagai faktor, salah satu penyangga penting adalah dalang. Kreativitas dalang senantiasa harus mengikuti perkembangan jaman untuk merefleksikan situasi, kondisi, dan jiwa zamannya (Rustopo. 2012, hlm. 1). Melihat fenomena tersebut, 
para seniman dalang semakin bangkit dalam upaya membangun kreativitas demi keberlangsungan hidup kesenian wayang. Dalam sebuah pertunjukan wayang yang baik, sudah barang tentu di dalamnya akan dijumpai kualitas penonton yang dapat memberikan kesenangan, keindahan, kenyamanan, dan halhal lainnya yang membangun suasana batin penonton yang larut dalam penikmatannya (Cahya, 2016, hlm. 121), maka kreativitas sangat penting dan memberikan peluang bagi para seniman dalang yang kreatif dalam menyikapi perkembangan zaman. Bahkan jika disikapi secara aktif dan berkelanjutan, akan terjadi suatu gebrakan pembaharuan dalam dunia seni pertunjukan wayang.

Seni pewayangan di Indonesia mengalami perkembangan yang mengikuti selera masyarakat dan kebutuhan masyarakat penggemarnya. Memasuki zaman modern, kemasan dari pertunjukan wayang semakin berkembang, hal tersebut merambah pada elemen pokok pembentuk kesenian seperti sarana dan prasarana serta setting, sampai unsur-unsur penunjang estetis di dalamnya seperti gerak (tetikesan), vokal, instrumen pengiring, dan lain-lainnya (Wicaksana, 2018, hlm. 28). Pertunjukan wayang mampu berkembang hingga saat ini disebabkan adanya faktor keaktifan sang aktor utama, yaitu seorang dalang untuk selalu menggali dan bereksperimen dalam dunia pedalangan.

Menurut I Nyoman Sedana (wawancara, 20 juli 2020), Perkembangan wayang saat ini dapat dibagi menjadi beberapa jenis seperti Wayang Inovasi, Wayang Modern, Wayang Kreasi Baru, dan Wayang Kontemporer. Identifikasi dan klasifikasi jenis-jenis wayang tersebut sebagai berikut: 1) Wayang Inovatif pada umumnya lebih menekankan pada pembaharuan seperti contoh Wayang Kaca karya I Wayan Wija, Wayang Kulit Cenk Blonk dengan dalang I Wayan Nardayana. 2) Wayang Modern lebih menekankan pada kemutakhiran teknologi yang digunakan terutama melibatkan apparatus elektronik seperti komputer dan teknik perfilman yang berintegrasi di dalamnya seperti contoh Cinema Puppet Teater karya Larry Reed bersama Shadowlight Productions, Wayang Listrik karya I Made Sidia bersama Sanggar Paripurna dan yang lainnya. 3) Wayang Kreasi baru menekankan pada unsur ciptaan dan kebaharuan baik dari isi dan bentuk hingga apparatus pertunjukannya seperti contoh Wayang Rai Wong Karya (alm) Ki Enthus Susmono, Wayang Kampung Sebelah karya Ki Jliteng Suparman. 4) Wayang Kontemporer lebih menekankan pada sifat kekinian yang sementara, sesaat, dan eksperimental seperti contoh Wayang Sampat Karya I Ketut Kodi, Pertunjukan (alm) Selamat Gundono yang menggunakan Wayang Suket sebagai media pertunjukannya, dan Wayang Ental karya I Gusti Made Darma Putra. Selain itu, karyakarya pewayangan lainnya juga menambah varian jenis pertunjukan wayang, sehingga membuktikan bahwa seni pewayangan mengalami perkembangan yang pesat.

Melalui jenis-jenis wayang yang mengalami perkembangan tersebut muncul berbagai konsep yang ditawarkan untuk para pengkaryanya. Salah satu konsep yang menjadi pilihan dalam penciptaan karya pewayangan oleh para penciptanya adalah konsep Teater Pakeliran yang merupakan sebuah konsep 
pertunjukan dengan memadukan seni teater dan seni Pewayangan (boneka).

Ketika terlalu mudahnya untuk menciptakan karya pewayangan yang menggunakan konsep teater pakeliran dengan hanya menambahkan unsur teater di dalam karya pewayangan menyebabkan konsep tersebut mulai mengalami keraguan oleh penontonnya, sehingga memerlukan sebuah pembahasan tentang keberdaan konsep teater pakeliran sebagai sebuah konsep yang popular dalam penciptaan karya pewayangan. Penulis mencoba mengkaji konsep teater pakeliran dari beberapa aspek, sebagai berikut: 1) teater pakeliran; 2) fenomena yang terjadi dalam konsep teater pakeliran; dan 3) potensi konsep teater pakeliran. Tujuannya adalah agar dapat mengetahui permasalahan yang terjadi untuk menemukan langkah pengembangannya.

\section{METODE}

Metode penelitian yang digunakan dalam proses penulisan karya ilmiah ini adalah metode kualitatif. Creswell dalam bukunya Penelitian Kualitiatif dan Desain Riset (2015, hlm. 182) mengemukakan bahwa pengantar dari studi kualitatif dimulai dari identifikasi masalah, yang kemudian dilanjutkan dengan dikemukakannya tujuan dari riset kualitatif yang dilakukan. Sejalan dengan definisi tersebut penulis melakukan serangkaian proses (praktik) yang mempergunakan rangkaian-rangkaian proses telaah dalam memperoleh dan menafsirkan secara sistematis bahan-bahan yang dikaji sehingga mengasilkan kesimpulan berdasarkan rumusan masalah (materi).
Kajian kualitiatif ini menggunakan jenis data primer berupa hasil dokumentasi video dan wawancara, diperkuat dengan data sekunder berupa kepustakaan terkait yang diaplikasikan langsung pada analisis bahasan yang dikaji yaitu: 1) bentuk pementasan wayang berkonsep teater pakeliran; 2) fenomena yang terjadi dalam konsep teater pakeliran; dan 3) potensi konsep teater pakeliran

Data primer dan sekunder didapatkan melalui teknik pengumpulan data yaitu, pertama observasi langsung yang dilakukan di satu tempat yaitu, kampus Institut Seni Indonesia Denpasar pada tanggal 11 Mei 2020, dilakukan langsung oleh penulis dengan mempersiapkan alat-alat berupa media rekam (handycam) serta kamera smartphone sebagai sarana dokumentasi.

Kedua, wawancarara tidak terstruktur, penulis mengajukan pertanyaan yang dirangkumsecaraumum danmengembangkan lagi pertanyaan berdasarkan alur bahasan yang ditujukan kepada narasumbernarasumber di antaranya; I Nyoman Sedana (65 tahun), I Gusti Putu Sudarta (54 tahun), I Dewa Ketut Wicaksana (56 tahun), I Ketut Kodi (56 tahun), I Ketut Suteja (58 tahun), dan I Kadek Widnyana (54 tahun) yang semuanya merupakan Dosen akademisi dibidang seni pertunjukan. Melalui metode wawancara ini didapatkan rekaman dengan total waktu berdurasi 1,5 Jam. Isinya membahas mengenai pandangan, pendapat, dan saran berkenaan dengan bahasan yang dikemukakan oleh narasumber. Kemudian video pertunjukan Teater Pakeliran: Sang Anom oleh Sang Nyoman Gede Adhi Santika (25 tahun); Teater Pakeliran 
Padat Prabha Kanya oleh I Kadek Prawira Nugraha (25 tahun); yang didapatkan penulis melalui sumbangsih seniman penggarapnya.

Ketiga, kepustakaan yang dilakukan dengan menelaah buku, artikel serta hasil kajian lainnya yang terkait dengan analisis serta kajian dalam bahasan.

Teori bentuk seni, teori kriktik seni, dan teori nilai seni, didukung metode analisis komparatif akan digunakan untuk menganalisis secara metodik dan sistematis sehingga mampu mengangkat, menguraikan, dan menganalisis aspek ontologis dari sebuah konsepsi garap seni dan penggunaanya. Pada akhir tulisan, penulis menganalisis nilai yang teraplikasi dalam konsep teater pakeliran tersebut.

\section{HASIL DAN PEMBAHASAN}

Teater Pakeliran Sebagai Konsep dalam Pertunjukan Wayang

Pertunjukan seni yang memadukan aktor dengan boneka dalam sebuah konsep karya seni pertunjukan sudah ada sejak dahulu, seperti yang disebutkan dalam buku form of puppet, sebagai berikut :

the appearance of living human being on the puppet stage is a factor that supports the "puppet characteristic" of the subject. this is nothing new in conteporary puppet theatre. (Tomanek, 2006, hlm. 110).

Namun, kombinasi antara boneka dan aktor tersebut tidak dapat diterima oleh para pemain teater klasik eropa pada saat itu, karena menurut mereka gerak laku aktor terlalu natural sehingga mengganggu gerak dari boneka yang memiliki keterbatasan. Hal tersebut tidak berlaku pada konsep teater pakeliran karena boneka diproyeksikan pada layar maka antara wayang dengan aktor memiliki ruang yang berbeda.

Teater pakeliran dapat dibagi menjadi dua suku kata yaitu teater dan pakeliran. Teater berasal dari kata Yunani yaitu theatron yang berarti tempat pertunjukan. Dalam perkembangannya kata teater memiliki arti lebih luas dan diartikan sebagai sesuatu yang dipertunjukan di depan orang banyak (Bandem, 1996, hlm. 9). Keberadaan teater daerah di Indoneisa lebih dikenal karena pertunjukannya yang bersifat tradisional. Kesenian-kesenian yang dapat didefinisikan sebagai bagian dari teater daerah seperti kesenian ludruk, reog, ketoprak, kentrung, gambuh wayang wong, janger, hingga pertunjukan wayang kulit.

Walaupun dalam arti harfiah dari wayang adalah bayangan, tetapi dalam kaitannya dengan teater tradisional wayang juga diartikan sebagai seni teater yaitu pertunjukan boneka di panggung dan sutradara ikut bermain di dalamnya berbeda dengan sandiwara atau film. Sutradara dalam pertunjukan wayang dikenal dengan sebutan dalang. Menurut jenis aktor dan aktrisnya, aneka ragam jenis wayang itu dapat digolongkan atas lima golongan, yaitu:

1. Wayang kulit, pelaku yang muncul di panggung adalah boneka-boneka dua dimensi yang terbuat dari kulit atau tulang belulang.

2. Wayang golek, pelaku yang muncul di panggung adalah boneka-boneka tiga dimensi yang terbuat dari kayu. 
3. Wayang wong atau wayang orang, pelaku yang muncul di panggung adalah orang.

4. Wayang beber, pelakunya hanya digambar di atas kertas lebar yang digulung, dan direntang (dibeber) dalam pertunjukan.

5. Wayang klithik, pelaku yang muncul di panggung adalah boneka-boneka terbuat dari kayu pipih.

Pakeliran adalah istilah yang ditujukan untuk sebuah pertunjukan wayang yang menggunakan medium kelir/layar sebagai medium utamanya. Dalam pertunjukan pakeliran juga menggunakan pencahayaan untuk memproyeksikan wayang agar mampu menghasilkan bayangan dari wayang tersebut. Keberadaan pakeliran saat ini sudah mengalami perkembangan sehingga muncul jenis-jenis pakeliran seperti Kelir berkembang; Kelir yang tersusun tiga; Kelir lebar; Kelir bulat; Kelir segi tiga; Kelir dinamis; dan lain sebagainya. Maka, teater pakeliran dapat didefinisikan sebagai sebuah pertunjukan wayang dengan memadukan teater (manusia) di dalamnya yang bertujuan untuk mempertegas suasana dan menambah kesan kebaharuan dalam seni pertunjukan pewayangan.

Asal mula penyebutan konsep teater pakeliran belum dapat pastikan dengan jelas, namun penulis meyakini bahwa penyebutan teater pakeliran muncul karena pengkarya terdahulu tidak ingin meninggalkan unsur tradisi yang diwarisi oleh lehururnya yaitu kelir/layar, maka medium apparatus tersebut dimasukkan kedalam konsep ini dan munculah identitas baru yaitu teater pakeliran.
Pertunjukan wayang eksperimental sebagai luaran dari konsep teater pakeliran, pertamakali muncul dan tertulis dalam kajian-kajian seni oleh lembaga institusi seni. Karya pakeliran dengan memanfaatkan media lam$\mathrm{pu}$, proyektor, follow spot, dan alat modern sejenisnya muncul dan berkembang sejak tahun 1987 di Akademi Seni Tari Indonesia (ASTI), salah satunya seperti yang dilakukan oleh I Ketut Kodi dan I Dewa Ketut Wicaksana dalam ujian akhir seni yang mengambil bentuk garapan pakeliran layar berkembang yang berlakon Arjuna Tapa dalam (kekawin arjuna wiwaha karangan Empu Kanwa) dengan judul garapan Anugrah (Wicaksana, 2005, hlm. 14-15).

Clive Bell (1913) berpendapat bahwa segenap seni penglihatan dan seni musik sepanjang masa memiliki bentuk penting sehingga seni itu dihargai orang. Bell mengatakan bahwa intisari dari seni adalah bentuk penting (significant form), sementara mengenai karya seni sudah barang tentu membahas mengenai seniman penciptanya (dalam Gie, 2004, hlm. 31). Sebagai sebuah konsep pemikiran, teater pakeliran membutuhkan daya cipta yang menitikberatkan kreatifitas seniman dalang untuk kemudian dibentuk, sehingga dapat dinikmati oleh pemirsanya.

Penelusuran terhadap karya-karya berkonsep 'pakeliran' dan 'teater' kemudian menggunakan 2 (dua) pertunjukan seni hasil eksperimentasi mahasiswa di Jurusan Pedalangan Insitut Seni Indonesia Denpasar sebagai bahan perbandingan.

Pertama, Teater Pakeliran: Sang Anom (2017) oleh Sang Nyoman Gede Adhi Santika (25 tahun). Garapan Teater Pakeliran dengan 


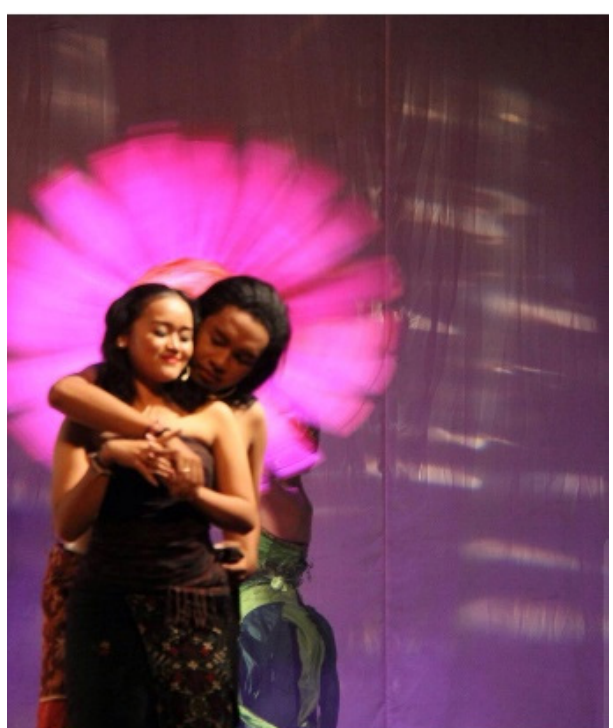

Gambar 1. Adegan teater Tokoh Sang Anom Bersama Tokoh Dewa Ayu Mas sedang memadu kasih (Sumber: Adhi Santika, 2017)

judul Sang Anom ini merupakan sebuah garapan pertunjukan eksperimental dengan memadukan beragam gagasan terkonsep, ke dalam kemasan pertunjukan seni yang mengangkat lakon Babad Ksatria Taman Bali.

Cerita garapan ini berawal dari pertemuan asmara antara Sang Anom dengan Dewa Ayu Mas, namun karena mereka terlarut dalam kisah cintanya mengakibatkan Dewa Ayu Mas hamil di luar pernikahan. Hal itu memicu kemarahan Raja Gelgel yang tiada lain ayah dari Dewa Ayu Mas.

Sang Anom pun dikejar dan ditangkap untuk dihukum dihadapan Raja, akan tetapi sebelum hukuman diterimanya, Dang Hyang Subali datang dan menerangkan semuanya sehingga Sang Raja terdiam menyadari bahwa Sang Anom tiada lain adalah keponakannya sendiri, dengan demikian direstuilah pernikahan Sang Anom dengan Dewa Ayu Mas dan menjadi awal dari kisah Ksatria Taman Bali.

Unsur-unsur teatrikal seperti gerak tari dialog dan monolog yang diperankan

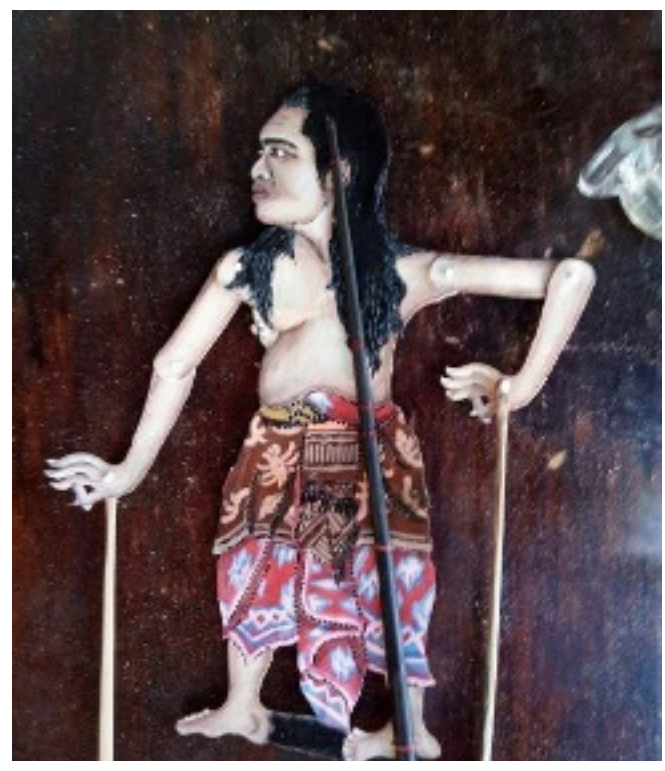

Gambar 2. Bentuk Wayang Sang Anom (Sumber: Adhi Santika, 2017)

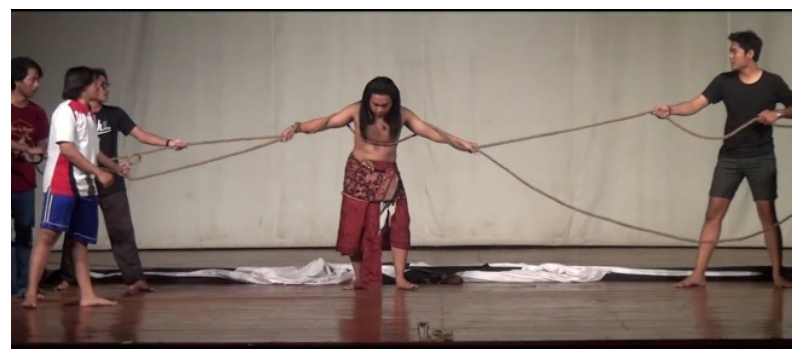

Gambar 3. Proses Latihan Teater Pakeliran Sang Anom

(Sumber: Adhi Santika, 2017)

langsung oleh tokoh manusia dipadukan secara langsung dengan unsur pewayangan yaitu wayang pipih dua dimensi, dan menggunakan iringan gamelan Jawa.

Latihan-latihan awal dilakukan, baik dari pemain wayang, pemain teater, dan penabuh, selain itu penuangan daya estetis dalam pembuatan properti seperti kain kamben yang telah dimodifikasi agar dapat berubah fungsi mengikuti perubahan karakter tokoh, demikian pula pembuatan wayang baru yang memakai kertas karton agar mempermudah dalam pembiayaan.

Latihan-latihan awal dilakukan, baik dari pemain wayang, pemain teater, dan penabuh, selain itu penuangan daya estetis 


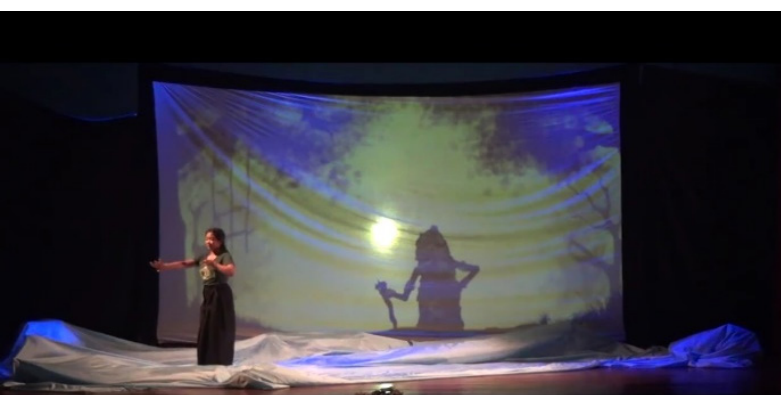

Gambar 4. Kombinasi Adegan Teatrikal Dengan Pewayangan Dalam Pertunjunjukan Sang Anom (Sumber: Adhi Santika, 2017)

dalam pembuatan properti seperti kain kamben yang telah dimodifikasi agar dapat berubah fungsi mengikuti perubahan karakter tokoh, demikian pula pembuatan wayang baru yang memakai kertas karton agar mempermudah dalam pembiayaan.

Sang Nyoman sebagai pemeran utama dapat dikatakan berhasil membawakan karakter tokoh Sang Anom dalam pementasannya. Secara keseluruhan penyajian pertunjukan teater pakeliran Sang Anom lebih banyak menampilkan unsur dramatikal berdasarkan pada aplikasi konsep yang matang.

\section{Kedua, Teater Pakeliran Padat Prabha} Kanya (2017) oleh I Kadek Prawira Nugraha (25 tahun) yang dipentaskan sebagai syarat Tugas Akhir (TA) penciptaan karya seni di Institut Seni Indonesia Denpasar. Karya pewayangan Prabha Kanya ini merupakan teater pakeliran padat yang menawarkan dan menyajikan sebuah karya pakeliran yang bersifat kreatif dan inovatif yang menggabungkan antara bentuk wayang dan teater, dengan mengangkat tema dari cerita tantri sehingga memberikan warna baru bagi dunia pedalangan.

Karya Teater Pakeliran Prabha Kanya diciptakan berdasarkan ide-ide dari perkembangangan karya pewayangan

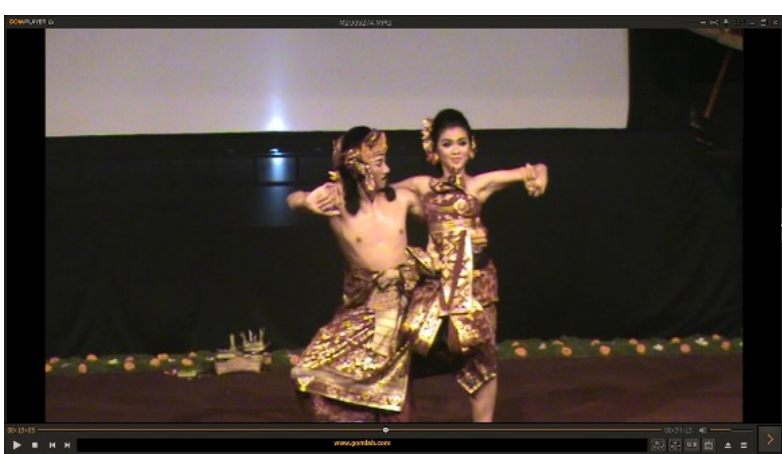

Gambar 5. Adegan Teatrikal Tokoh Dyah Tantri Dengan Prabu Hiswaryadala Dalam Pertunjukan Prabha Kanya.

(Sumber: Prawira Nugraha, 2017)

yang ada di Bali, diadopsi dari cerita Tantri dan dikemas melalui pertunjukan wayang yang digabungkan dengan teater dengan mengangkat pesan dan fenomena-fenomena kekinian yang berkembang di masyarakat seperti banyaknya kasus kesenjangan terhadap perempuan, penyimpangan seksual, human trafficking, eksploitasi sanita, dan penjualan perempuan merupakan salah satu ide dari isi garapan yang akan diterjemahkan melalui pertunjukan wayang. Kata Prabha Kanya dapat dibagi menjadi dua kata yaitu 'Prabha' berarti sinar, bersinar dan 'Kanya' berarti gadis, dara, anak perempuan (Mardiwarsito, 1978, hlm. 243 dan 132). Kepentingan sebuah judul dalam karya ini dua suku kata tersebut disatukan menjadi Prabha Kanya yang berarti sinar seorang perempuan. Kata sinar dalam judul karya tersebut merujuk pada sebuah kecerdasan atau kepandaian. Karya tersebut terinspirasi dari cerita Tantri yang umumnya dikenal sebagai cerita berbingkai.

Menggarap karya pewayangan Prabha Kanya memerlukan konsentrasi, untuk menyatukan ide gagasan karya secara menyeluruh, dengan harapan dapat menghasilkan karya yang mampu 


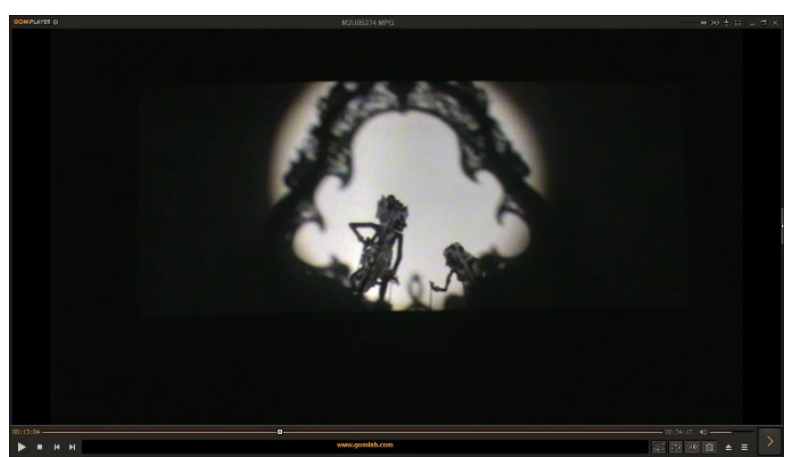

Gambar 6. Adegan Wayang Tokoh Dyah Tantri Dengan Prabu Hiswaryadala Dalam Pertunjukan Prabha Kanya.

(Sumber: Prawira Nugraha, 2017)

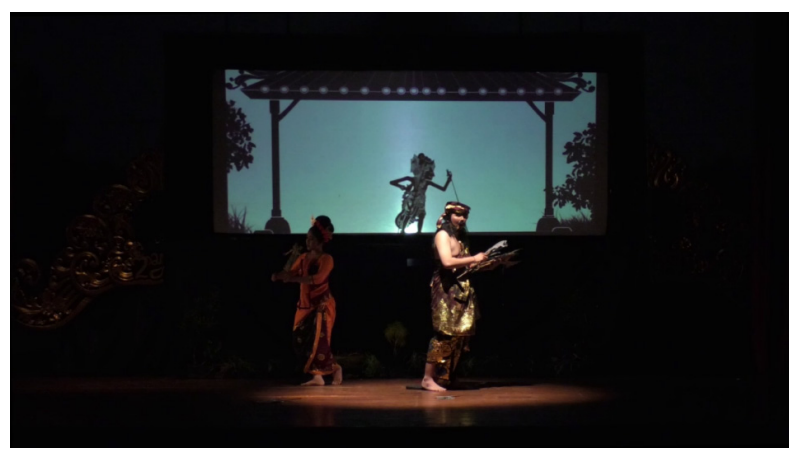

Gambar 7. Kombinasi Adegan Teatrikal Dengan Pewayangan Dalam Pertunjukan Prabha Kanya (Sumber: Prawira Nugraha, 2017)

menguraikan kedua konsepsi ‘teater pakeliran padat' secara detail (wawancara Prawira Nugraha, 11 Mei 2020). Melalui peningkatan teknikgerak wayang, penokohan teater, drama, dialog wayang, dan keutuhan karya, Prawira Nugraha berkeinginan untuk menyampaikan pesan dan paham feminimisme, di mana dalam karya Prabha Kanya tersebut terlihat jelas tokoh Ni Diah Tantri dan Ni Mesaba Sebagai karakter feminim mampu memberikan ilmu kecerdasan dalam mengadapi tantangan.

Sebagai sebuah karya ekperimental 'teater pakeliran padat' Prabha Kanya karya Prawira Nugraha menuangkan konsepsi teater dan pakeliran secara terstruktur dalam pembabakannya secara tertulis. Hal ini kemudian mempermudah identifikasi terhadap proporsi dari masing-masing konsep yang digunakan.

Pengamatan terhadap dua bentuk pertunjukan wayang tersebut, dapat disimpulkan bahwa aspek penting yang menjadi pondasi kuat terbangunnya nilai-nilai keindahan dalam sebuah pertunjukan wayang adalah pematangan dari abstraksi ide serta gagasan seniman dalang yang terpetakan ke dalam sebuah skema berfikir dan tertulis yang muncul sebagai 'konsep'. Konsep menjadi hal vital yang seyogyanya dimatangkan terlebih dahulu sebelum sebuah karya seni khususnya seni dibidang pewayangan, untuk dieksekusi ke dalam rupa-bentuk seni pertunjukan.

\section{Problematika dalam Konsep Teater Pakeliran.}

Sejauh mana orang dapat memberikan makna terhadap pertunjukan wayang itu sesungguhnya bergatung pada pemahaman dan kepentingan tiap-tiap individu (Suyanto, 2013, hlm. 6). Maka dialektika tentang pertunjukan wayang masa kini terus bergulir dari pembahasan yang menyebut seni pewayangan mengalami penurunan karena fenomena yang terjadi yaitu pertunjukan pewayangan saat ini sebagai bali-balihan atau hiburan tergerus oleh globalisasi dengan berbagai jenis hiburan khas modern, baik kehadiran televisi yang menampilkan banyak hiburan, begitu juga smart phone yang mampu menarik perhatian masyarakat secara personal. Masyarakat seperti hanyut pada globalisme universal yang menuntut manusia untuk terus-menerus meningkatkan taraf hidup berdasarkan persaingan yang ketat, bebas, dan terbuka (Putra, 1998, hlm. 15).

Seni pewayangan di sisi lain juga 
mengalami perkembangan, terlihat dari munculnya karya-karya eksperimental yang mampu mewakili perkembangan tersebut, seperti pertunjukan wayang dengan menggunakan alat-alat elektronik dan lain sebagainya. Selain karya pewayangan, jumlah dalang juga mengalami perkembangan bahkan muncul beberapa dalang wanita yang mampu menyaingi keterampilan memainkan wayang, layaknya seperti para dalang pria.

Menyikapi dualisme tersebut. maka dapat dikatakan bahwa secara kuantitas seni pedalangan mengalami perkembangan namun secara kualitas mengalami penurunan, pernyatan tersebut langsung di konter oleh pandangan bahwa penurunan kualitas yang dimaksud yaitu para pencipta karya pewayangan menciptakan karya dengan menggunakan konsep teater pakeliran namun tidak memahami secara mendalam tentang keberadaan konsep tersebut yang menyebabkan muncul bahasa "yang penting misi (yang penting isi saja)" baik dari penambahan teater atau pakelirannya. Sedangkan secara mendasar konsep teater pakeliran harus mensinergikan antara teater dan wayang atau pakeliran tersebut.

Konsep teater pakeliran sebagai sebuah genre yang populer dalam seni pedalangan mulai diragukan oleh penontonnya, terlihat dalam pertunjukannya keberadaan teater akan lebih mendominasi karena teater lebih mudah digarap sedangkan fungsi medium kelir yang digunakan hanya sebagai penunjang dan wayang yang muncul dalam kelir tidak memiliki porsi yang lebih banyak apabila dibandingkan dengan keberadaan teater (manusia). Tanggapan tersebut memiliki persamaan dengan Tomanek (2006, hlm. 7) yang menyebutkan bahwa:

"On a stage that has been designed for puppets of smaller proportions, the live actor seems too dominant and takes on a special relationship with the puppet"

Berdasarkan penjelasan tersebut, maka diperlukan adanya rumusan yang tepat untuk mengomposisikan sebuah konsep teater pakeliran sebagai sebuah genre yang populer digunakan dalam kalangan seniman dalang khususnya dalang kontemporer saat ini.

Ketika perkembangan teater pakeliran sangat eksis sebagai sebuah konsep penciptaan pewayangan, pengaryaanya mulai tidak menghiraukan elemen-elemen kecil yang berpengaruh besar dan dapat berdampak buruk pada pertunjukan teater pakeliran tersebut. Adapun elemen-elemen tersebut seperti gerak laku aktor yang berlebihan dari wayang, transisi dari pakeliran ke teater, dan warna kostum aktor yang terlalu mencolok seperti merah, kuning, hijau, dll. Jika berdampingan dengan wayang yang hanya sebuah bayangan dengan warna hitam dan putih, maka wayang akan mengalami penurunan kualitas daripada aktor. Pernyataan penulis, didukung oleh pendapat Tomanek (2006, hlm. 7) yang mengatakan bahwa "the colour of the puppeteer's costume verses the colour of the puppet, larger movements of the puppeteers, his gestures, small mcvements of the puppet's abilities, etc". Hal kecil seperti ini akan berdampak besar pada teater pakeliran.

'Konsep' bermain di ranah ide dan gagasan yang terkadang sulit untuk dipetakkan. Analisis kritis terhadap dituangkannya sebuah ide garapan oleh 
seniman, kerap kali menemui hambatan dan kendala yang umumnya disebabkan oleh gagasan itu muncul dan menghilang dalam proses penggarapannya. Terdapat pula seniman dengan daya kreatifitas tinggi serta cakupan wawasan yang luas, kerap kehilanggan ide dan gagasan yang didapatkannya karena kurangnya keinginan untuk memetakanya terlebih dahulu ide-ide tersebut ke dalam peta konsep berfikir.

Terlebih dalam menggunakan konsep teater pakeliran sebagai sebuah bentuk seni pertunjukan eksperimental dalam menyajikan karya seni khususnya di bidang pewayangan dan pedalangan, dengan tujuan penilaian estetik.

Jhon Hospers dalam buku Filsafat Wayang Sistematis (2017) oleh Solichin. H, dkk. memberi penjelasan bahwa estetika adalah cabang filsafat yang berkenaan dengan analisis konsep-konsep dan pemecahan persoalanpersoalan yang timbul bilamana orang merenungkan tentang benda-benda estetis yang terdiri atas semua benda estetis (Solichin, 2017, hlm. 271). Dikatakan pula bahwa dengan demikian, hanya setelah pengalaman estetis dapat secukupnya dinyatakan ciri-cirinya, orang mampu menentukan batas-batas dari kelompok-kelompok benda-benda estetis itu.

Adhi Santika sebagai penggarap teater pakeliran Sang Anom menuturkan bahwa konsepsi teater pakeliran Sang Anom yang digarap dan ditampilkannya merupakan implementasi dari berbagai mata kuliah yang dipelajarinya di jurusan pedalangan pada semester semester sebelumnya (wawancara Adhi Santika, 11 Mei 2020). Widnyana selaku dosen sekaligus ketua Prodi Pedalangan juga menerangkan pendapat yang hampir sama yaitu, jurusan/program studi pedalangan merupakan salah satu jurusan/program studi yang materi serta luaran mata kuliahnya mencakupi berbagai macam kelimuan dibidang seni, dari seni rupa hingga seni pertunjukan (wawancara Widnyana, 9 Mei 2020). Luasnya cakupan dari bidang keilmuan yang diberikan dalam perkuliahan juga berdampak pada kekaryaan yang akan diciptakan, maka perlunya kepekaan dari pengarya dalam hal ini mahasiswa, agar memikirkan dengan matang dalam perencanaan konsep. Luaran akhir dari ilmu yang diperoleh kemudian akan diuji secara ilmiah dan metodik dalam proses tugas akhir.

Populernya konsep teater pakeliran sebagai ide dan gagasan yang terpetakkan sebagai pondasi penggarapan karya mahasiswa di jurusan pedalangan, cenderung disebabkan karena dimensi teater pakeliran yang mencakupi luasnya ilmu serta luaran yang ingin dicapai oleh mahasiswa dalam menampilkan karya seni, di samping teater pakeliran telah merangkum sebagaian besar materi pembelajaran yang diperoleh siswa selama mengikuti perkuliahan.

Konsepsi teater pakeliran oleh seniman dalang akademisi melahirkan sebuah karya seni pedalangan yang kompleks, untuk dapat dinilai secara teoritis dan metodik sebagai produk seni unggulan bernilai dan berbobot. Sumber nilai dari setiap karya seni pada dasarnya berkaitan langsung dengan tiga komponen utama yang menunjang kehidupan seni di masyarakat yaitu hubungan antara seniman, karya seni, dan penghayat (Kartika, 2007, hlm. 4). 
Konsep teater pakeliran sebagai produk yang dilahirkan dari proses penggalian, pemahaman, dan rangkuman pengetahuan yang didapatkan dan dimiliki dalang, berimplikasi secara langsung pada diri sang dalang hingga ke ruang lingkup sosialnya. Dalam konteks penciptaan karya seni eksperimental, seniman 'mahasiswa' akan saling berkutat mengajukan ide-ide baru dengan gaya tersendiri, dengan tujuan bersaing antara satu dengan yang lainnya untuk menampilkan karya terbaik. Mereka yang memiliki wawasan, pengalaman, status sosial, serta sumber daya yang memadai akan menciptakan karya seni pedalangan terbaik. Namun, dalam beberapa kasus mahasiswa yang mampu mencari ide, mengonsepsikan karya dengan matang, serta mempunyai wawasan, dan pengalaman yang mumpuni dapat menciptakan karya yang mempunyai nilai estetis serta daya saing yang sepadan dengan yang lainnya.

Masalah yang dihadapi oleh seniman akademisi ketika menggarap karya seni eksperimental tidak berhenti pada tahap pemetaan ide-ide dan gagasan dalam menanggapi kondisi faktual, untuk kemudian dijawab melalui nilai-nilai yang dicoba untuk disajikan melalui karyanya, melainkan proses berlanjut pada tahapan eksekusi karya, dan sang seniman mulai berinteraksi penuh dengan pendukung untuk membangun karyanya.

Adhi Santika (wawancara, 2020) menuturkan bahwa latihan-latihan awal, baik dari pemain wayang, pemain teater, dan penabuh, serta penuangan konsep dalam pembuatan properti seperti kain kamben,

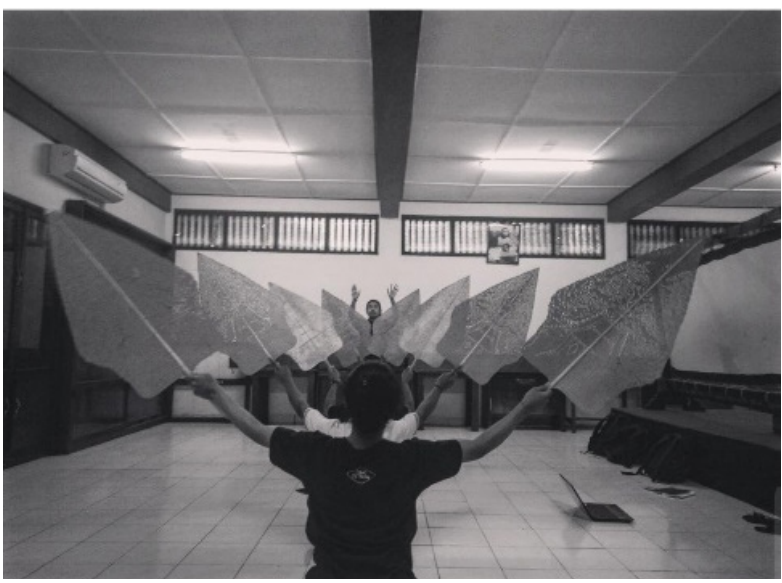

Gambar 8. Wayang Kayonan gagrak Jawa dalam pertunjukan Sang Anom (Sumber: Adhi Santika, 2017)

dimodifikasi agar dapat berubah ketika tokoh juga berubah. Demikian pula halnya dalam pembuatan wayang baru yang memakai kertas karton dan solek agar mempermudah pembiayaan.

Wayang-wayang baru yang dibuat adalah; wayang gunungan Jawa, wayang tokoh Dang Hyang Subali, Sang Hyang Aji Rembat, Sang Anom, dan Ni Dewa Ayu Mas. Penggarap terlebih dahulu memfoto orangorang yang akan dijadikan salah satu tokoh, agar dalam pembuatan wayangnya sama persis ketika akan memakai adegan tiga dimensi.

Pembuatan properti seperti pakaian dan dekorasi diserahkan kepada panitia yang sudah dibentuk. Modifikasi kamben yang dipakai oleh tokoh utama; pertama kamben batik dipakai oleh tokoh kakek, ketika akan berubah menjadi tokoh Sang Anom di panggung kamben itu hanya dibalik dan berubah menjadi kamben endek berwarna merah. Penggunaan objek kelir yang yang telah dikonsep terpadu dengan adegan teater juga dimunculkan dalam adegan teater pakeliran Sang Anom. Sebagai bentuk nyata 


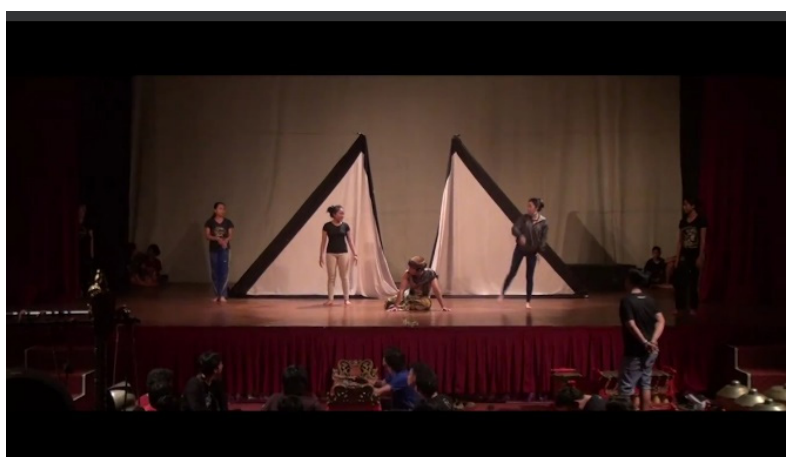

Gambar 9. Kelir (Kain) Berkerangka Besi Modifikasi, Berfungsi Sebagai Gapura (Sumber: Adhi Santika, 2017)

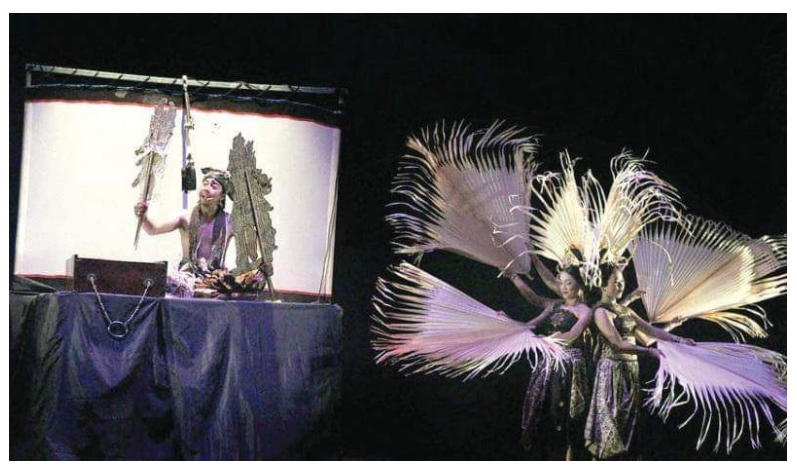

Gambar 10. Wayang Inovatif 'Wayang Ental' karya I Gusti Made Darma Putra

(Sumber: Darma Putra, 2016)

dari proses eksplorasi elemen-elemen karya seni dan teraplikasikannya konsep teater pakeliran tersebut.

Hal itu juga dilakukan pada tokoh nenek yang akan menjadi tokoh Ni Dewa Ayu Mas dalam beberapa adegan. Properti yang mendukung sangat diperlukan agar adegan yang dimaksud lebih jelas dipaparkan. (wawancara, 12 Mei 2020). Berdasarkan hal tersebut diketahui bahwa, proses penggarapan sebuah karya seni eksperimental dengan menggunakan konsep karya teater pakeliran membutuhkan semangat, daya cipta, intuisi, hubungan sosial, serta sumber daya dalam penggarapannya.

Selain pertunjukan teater pakeliran Sang anom dan Teater Pakeliran Padat Prabha Kanya terdapat pula pertunjukan lainya yang secara visual menampakkan konsep 'teater pakeliran' yaitu Wayang Ental lakon Purusadha Santa karya penulis.

Berkenaan dengan tahapan yang dilakukan, dapat diceritakan bahwa, setelah mematangkan ide dan penentuan cerita, penggarap mulai memikirkan tata panggung pertunjukan, musik pengiring, dan pola struktur lakon yang akan digunakan. Penggarap juga memikirkan unsur-unsur estetika dalam garapan Wayang Ental ini untuk mempertegas isi garapan tersebut. Penggarap menemui bapak I Ketut Kodi, SSP., M.Si., bertempat di Kampus ISI Denpasar pada tanggal 12 Februari 2016. Beliau menyarankan agar gagasan mengenai teknis penyajian pada adegan awal pertunjukan dikemas dalam sajian prolog yang mengedepankan konsep 'kebhinekaan' sebagai suatu keindahan dan kelumrahan dalam kehidupan manusia yang diciptakan dengan anekaragam suku, bangsa, dan agama.

Konsep garap seperti sudah tampak nyata, penggarap segeramenemui AnakAgung Gede Rahma Putra, SSn., M.Sn., pada tanggal 19 Februari 2016. Melalui wawancara tersebut penggarap mendapat inspirasi tentang teknik penggunaan ental dalam pertunjukan seni, termasuk wawancara dengan I Made Setiaria, SSn., M.Sn., pada tanggal 29 Februari 2016.

Langkah selanjutnya mencari perajin ental untuk membuat wayang yang berbahan ental ke Desa Bona dan bertemu dengan I Gusti Ketut Sentana Putra, seorang perajin ental dan anyaman bambu. Ketika diwawancarai, pada tanggal 2 Maret 2016, beliau memberikan masukan mengenai teknik ulatan Wayang Ental pada tokoh-tokoh seperti Sutasoma, Purusada, 


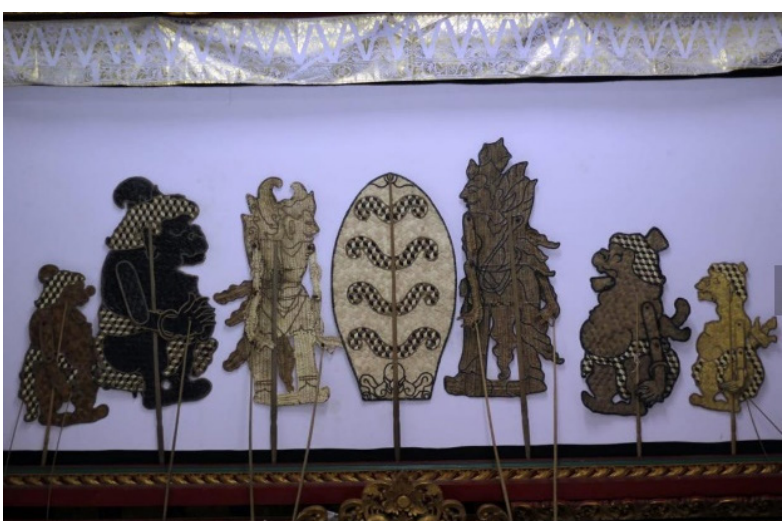

Gambar 11. Bentuk Wayang Ental (Sumber: Darma Putra, 2016)

dan Dasabahu dengan teknik ulatan sumpe menggunakan kerangka besi. Sedangkan wayang tokoh punakawan menggunakan anyaman Jepang dengan mengkombinasikan beberapa warna sesuai dengan kebutuhan.

Penggarap juga mendekati para pendukung untuk dapat membantu mensukseskan garapan Wayang Ental, maka bantuan stage crew sangat dibutuhkan untuk menyukseskan pementasan. Stage crew berperan dalam memadukan tata panggung dan pencahayaan yang sesuai untuk mempertajam suasana yang akan dimunculkan dalam setiap adegan. Pada tahap ini dilakukan latihan sektoral dengan mengikutkan para pendukung garapan untuk mengetahui alur cerita, dramatik panggung yang akan ditampilkan, agar dapat memahami dan menguasai instruksi dari konsep-konsep yang ke dalam karya garapan.

Pendukung pemain wayang dari garapan ini adalah mahasiswa Program Studi Seni Pedalangan, FSP ISI Denpasar dan penari dari siswi SMKN 3 Sukawati, Gianyar. Harapan besar ditumpukan kepada para pendukung agar memiliki rasa tanggungjawab yang optimal, sehingga lebih

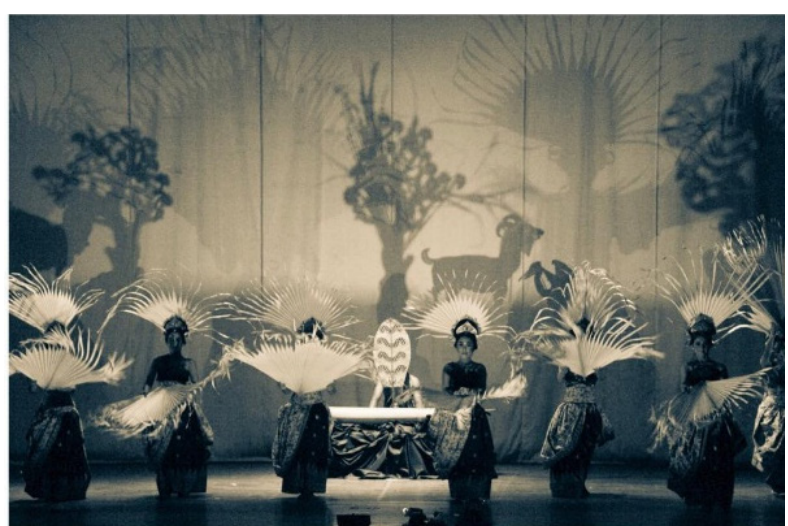

Gambar 12. Adegan Teatrikal dan Wayang Ental Bersinergi dengan Bayang-Bayang Wayang Tradisi (Sumber: Darma Putra, 2016)

siap untuk mendukung kelancaran proses garapan Wayang Ental ini.

Para pendukung yang diperlukan dalam garapan ini adalah 20 (dua puluh) orang termasuk penari. Kombinasi seluruh elemen dalam perpaduan konsep pewayangan dan teatrikal menghasilkan gubahan visual yang cukup estetik.

Menghasilkan karya seni pewayangan inovatif, dibutuhkan seorang penata iringan (composer). Mengamati kebutuhan suasana setiap adegan dalam garapan ini, penggarap memutuskan untuk menata musik iringannya. Dibantu seorang sahabat bernama I Komang Winantara untuk menata iringan ini. Dipilih instrumen gamelan mini Semarapagulingan saih pitu yang diselingi dengan gamelan Batel Wayang, untuk memperkuat suasana dalam adegan perang (pasiat) dan lainnya, sebagai aksentuasi atau penekanan tegas dan keras.

Konsep teater pakeliran membutuhkan pemetaan konsep secara mendasar. Menyimak salah satu proses karya seni eksperimental oleh Adhi Santika, dapat dibayangkan betapa kompleks dan rumitnya penggarapan sebuah pertunjukan wayang yang dapat dipertanggungjawabkan secara keilmuan. 
Didasarkan pokok-pokok proses yang diikuti dalam kasus-kasus kecil yang tidak dapat dideskripsikan secara rinci oleh penggarap, maka konsep teater pakeliran sebagai pondasi dasar penciptaan karya seni membutuhkan suatu pemetaan dan formulasi khusus untuk dapat dijadikan pedoman berfikir dalam merumuskan ide-ide dan gagasan para seniman dalang. Dalam perkembanganya kelak formulasi yang telah terukur serta terpetakan tersebut akan menjadi gambaran dasar sebuah konsep 'teater pakeliran'. Secara terstruktur dan metodik formulasi tersebut dapat mempermudah proses kreatifitas mahasiswa dalam menentukan persentase dan perimbangan-perimbangan masing-masing aspek pada bagian teater atau pakelirannya.

\section{Potensi 'Konsep Teater Pakeliran' sebagai Sebuah Nilai}

Kreativitas merupakan hasil dari interaksi individu dengan lingkungannya, kemampuan untuk membuat kombinasi baru berdasarkan data, informasi, unsurusur yang sudah ada atau dikenal dengan pengalaman, dan pengetahuan yang telah diperoleh seseorang selama hidupnya baik itu di lingkungan, sekolah, keluarga, maupun alam sekitarnya (Iswantara, 2017, hlm. 7). Kreativitas seniman terkadang diperolah dari hal-hal yang berada di lingkungan seniman tersebut yang mampu merangsang munculnya ide gagasan penciptaan suatu karya seni.

Lebih lanjut mengenai nilai dalam seni, Jakob Sumarjo (2000, hlm. 140) mengemukakan bahwa nilai-nilai dasar dalam seni apapun dapat disimak sebagai berikut ini. Nilai pertama dalam seni adalah nilai penampilan (appearance) atau nilai wujud yang melahirkan nilai seni. Nilai ini terdiri dari nilai bentuk dan nilai struktur. Nilai kedua adalah nilai isi (content) yang dapat terdiri atas nilai pengetahuan (kognisi), nilai rasa, intuisi, nilai religi, dsb. Nilai ketiga adalah nilai pengungkapan (presentation) yang dapat menunjukan adanya nilai bakat pribadi seseorang, nilai keterampilan, dan nilai medium yang dipakainya

Nilai yang terkandung dalam bentuk wayang eksperimental hasil karya seniman dalang, menjadi panutan beberapa dalang atau komunitas penggiat di bidang pedalangan dan pewayangan lainnya dalam menciptakan wayang-wayang serupa. Muatan estetis sebagai hasil dari pematangan konsep teater pakeliran tersebut berpotensi memberikan pengaruh positif bagi peningkatan dan pengembangan sinergitas bidang ilmu dan seni. Bagi individu seniman atau komunitas pedalangan, baik akademisi maupun nonakademisi tentu akan sangat berguna membantu meningkatkan daya cipta seni, sehingga muncul hasil kreativitas seni wayang yang berkualitas, berdaya saing, dan pastinya sinergitas antarseniman dengan disiplin ilmu yang beragam.

Umumnya apa yang disebut "indah" karena dapat menimbulkan rasa senang dalam jiwa, rasa bahagia, rasa tenang, rasa nyaman, dan bila kesannya lebih kuat, membuat penikmat terpaku, terharu, dan timbul keinginan untuk kembali menikmatinya (Djelantik, 1990, hlm. 1-2).

Konsepsi teater pakeliran dengan formula yang tepat dan susunan serta struktur 
yang terpadu digubah dari elemen terkecil hingga besar, berpeluang memunculkan nilainilai estetis di dalamnya. Walau pada mulanya karya-karya tersebut wajib melalui pengujian dan harus dapat dipertanggungjawabkan secara teoritis dan metodik, namun dapat dipastikan unsur-unsur yang membangun ciri keindahan dalam karya seni akan dapat diwujudkan.

Sajian teater pakeliran sangat ditentukan oleh unsur-unsur estetis yang tercermin lewat tetikesan (gerak wayang), antawacana (dialog tokoh wayang), tutur (petuah), sendon (tembang), kemudian dipadukan dengan elaborasi iringan gamelan, sehingga orang menjadi tertarik, senang, dan betah menontonnya. Selain angkaian proses panjang dalam penyajian pertunjukannya, wayang berkonsep teater pakeliran, hasil kreativitas seniman dalang khususnya mahasiswa dari Jurusan Seni Pedalangan ISI Denpasar menggunakan rangkaian tahapan-tahapan dengan melibatkan seniman lain di luar disiplin ilmunya, seperti seniman pengerawit, seniman tari hingga, pengajar seni yang umumnya diketahui mengikuti perkuliahan di Jurusan Sendratasik ISI Denpasar.

Melalui keterangan ketua Prodi Jurusan Seni, Drama, Tari, dan Musik (Sendratasik) Institut Seni Indonesia Denpasar Drs. Rinto Widyarto M.Si, bahwa jurusan tersebut telah menerapkan sebuah matakuliah bernama 'drama wayang' di mana para siswanya diberikan tugas akhir meneliti dan menampilkan sebuah pementasan sederhana yang mensinergikan kisah-kisah, tokoh, dan instrumen alat dalam dunia pewayangan dengan seni pertunjukan drama yang mengutamakan kehadiran tokoh serta pemeran secara langung di panggung, yang berhadapan dengan penonton. Kehadiran matakuliah tersebut secara tidak langung mengaplikasikan konsep drama yang mewakili 'teater' serta wayang yang mewakili 'pakeliran' sebagai sebuah kombinasi pemikiran dalam merangkum ide dan gagasan bagi seniman dalang.

\section{SIMPULAN}

Teater Pakeliran sebagai sebuah produk berfikir konseptual, oleh mahasiswa Program Studi Pedalangan secara aplikatif menerapkan sitematika proses penggarapan karya seni berbasis riset. Konsep dalam karya seni eksperimental yang berbentuk ide atau gagasan mahasiswa, tertuang ke dalam satu pemetaan terstuktur, metodik, dan teoritik dalam kerangka kerja yang terbungkus proses panjang dan kompleks. Guna memberikan gambaran terhadap konsep teater pakeliran dalam penggarapan karya seni digunakan Teater Pakeliran Sang Anom, Teater Pakeliran Padat Prabha Kanya, dan Wayang Ental lakon Sutasoma

Adopsibudaya coba-coba dankurangnya intuisi serta pengalaman, dalam berkreatifitas seni memunculkan permasalahan pada konsep' sebagai gambaran awal sebuah karya seni yang semestinya dipetakan dan diformulasikan dengan matang terlebih dahulu. Hal ini kemudian akan mempermudah penggarapan karya seni, khususnya karya seni tuntutan proses garap dan hasil yang dapat dipertanggungjawabkan secara teoritis dan metodik. Karya Sang Anom, Prabha Kanya, dan 
Wayang Ental merupakan karya-karya yang secara ideal telah menerapkan konsep teater pakeliran di dalamnya.

Disinergikannya aspek drama (teatrikal) dan pewayangan (pakeliran), ke dalam paradigma berkesenian khususnya seni pertunjukan merupakan hal yang harus digemakan karena memiliki potensi keilmuan yang sangat tinggi dan sarat akan nilai pendidikan estetis. Sebagai sebuah kasus yang masih perlu didalami, teater pakeliran di dalam pertunjukan wayang eksperimental nampak memberi peluang, bertumbuhnya sebuah konsep pemikiran baru dalam berkarya. Peluang ini harus terus diuji, dikembangan seraca teoritis dan praktis sehingga dapat bergerak dinamis sesuai kebutuhan dan kapasitas sang seniman dalang dalam berkarya.

\section{DAFTAR PUSTAKA}

Bandem, I Made dan Sal Murgiyanto. (1996). Teater Daerah Indonesia, Yogyakarta : PT Kanisius

Cahya. (2016). “Nilai, Makna, Dan Simbul Dalam Pertunjukan Wayang Golek Sebagai Representasi Media Pendidikan Budi Pekerti". Dalam Jurnal Seni dan Budaya Panggung. Vol. 26, No 6.

Creswell, Jhon W. (2015). Penulisan Kualitiatif dan Disain Riset. Pustaka Pelajar. Yogyakarta.

Djelantik, A.A. M. (1990). Pengantar Dasar Ilmu Estetika Jilid I Estetika Instrumental. Sekolah Tinggi Seni Indonesia Denpasar (STSI), Denpasar.

Gie, The Liang. (2004). Filsafat Seni. Pusat Belajar Ilmu Berguna (PUBIB). Yogyakarta.
Iswantara, Nur. (2017). Kreativitas, Sejarah, Teori dan Perkembangan. Gigih Pustaka Mandiri.

Jakob Sumardjo. (2000). Filsafat Seni, Penerbit ITB. JL Ganesa 10, Bandung

Jakob Sumardjo. 2000. Filsafat Seni, Penerbit ITB. JL Ganesa 10, Bandung

Kartika, Dharsono Sony. (2007). Kritik Seni. Rekayasa Sains Bandung.

L. Mardiwarsito. (1978). Kamus Jawa Kuna Indonesia. Flores. Nusa Indah

Putra, IB Wyasa. (1998). Bali Dalam Perspektif Global. Denpasar : PT Upada Sastra.

Rustopo. (2012). Seni Pewayangan Kita; Dulu, Kini dan Esok. ISI Press. Solo.

Solichin. H, dkk (Tim Filsafat Wayang), (2016) .Filsafat Wayang Sistematis, SENAWANGI, CV Dedy Jaya. Jakarta

Suyanto. (2013). “Pertunjukan Wayang Sebagai Salah Satu Ruang Mediasi Pendidikan Budi Pekerti". Dalam Jurnal Seni dan Budaya Panggung. Vol. 23, No 1.

Tomanek, Alois. (2006). Forms Of Puppets. Praguu : Academy Of Performing Arts. Wicaksana, I Dewa Ketut. (2005). "Pakeliran Layar Lebar Kreativitas Wayang Berbasis Lokal Berwawasan Global" dalam WAYANG: Jurnal Ilmiah Seni PeWayangan, Volume 4, 1 September 2005, Program Studi Seni Pedalangan, Institut Seni Indonesia, Denpasar.

Wicaksana, I Dewa Ketut. (2018). “Bentuk dan Gerak Wayang Kaca Dalam Pentas Wayang Tantri, Sebuah Kreativitas Seni Modern berbasis Kebudayaan Lokal". Dalam Jurnal Pantun. Vol. 3, No. 1. Pp 28-41. 